\title{
Diagnostic Guide: Fusarium Crown Rot of Winter Wheat
}

\author{
Christina H. Hagerty, ${ }^{1,+}$ Tessa Irvine, ${ }^{1}$ Hannah M. Rivedal, ${ }^{2}$ Chuntao Yin, ${ }^{1,3}$ and Duncan R. Kroese \\ ${ }^{1}$ Columbia Basin Agricultural Experiment Station, Oregon State University, Adams, OR 97810 \\ ${ }^{2}$ Hermiston Agricultural Research and Extension Center, Oregon State University, Hermiston, OR 97838 \\ ${ }^{3}$ Department of Plant Pathology, Washington State University, Pullman, WA 99164
}

Accepted for publication 4 January 2021.

Keywords: fungi, cereals, Fusarium culmorum, Fusarium pseudograminearum

Hosts: Fusarium crown rot (FCR) can infect all major winter cereals, including wheat, oats, barley, and rye (Kazan and Gardiner 2018; Kirby et al. 2017).

Disease: The official common name is Fusarium crown rot. Other common names include dryland foot rot, dryland root rot, and Fusarium root rot (Kirby et al. 2017).

Pathogen: FCR is caused by species of the parasitic fungus genus Fusarium. Fusarium culmorum and F. pseudograminearum are the most prevalent and important (Kirby et al. 2017).

\section{Taxonomy}

Kingdom Fungi, division Ascomycota, class Sordariomycetes, order Hypocreales, family Nectriaceae, genus Fusarium, species Fusarium culmorum and F. pseudograminearum. Updated taxonomy can be found at MycoBank database (https://www. mycobank.org).

\section{Yield Loss}

Yield loss to FCR varies from year to year, depending on the severity of the infection and the conditions (Smiley et al. 2005), but is generally around $10 \%$ and can, under the right circumstances, be over $30 \%$. Plants undergoing water stress are more susceptible to FCR (Kirby et al. 2017).

\section{Signs and Symptoms}

Signs of the pathogen can be seen in infected plants as whiteish, pinkish, orangish, or reddish mycelial growth on the outside of the infected area, as well as within the stem (Figs. 1 and 2). The colonization of the stem by mycelium inhibits the flow of water and nutrients, leading to disease symptoms (Bockus et al. 2010; Kazan and Gardiner 2018).

FCR will cause stand reductions in crops at a landscape level. Early season damping-off can occur at seedling emergence in the autumn, particularly when seeding occurs in cool moist soil conditions. In individual plants, symptoms will include the rotting of seeds, seedlings, roots, crowns, subcrowns, and lower stem tissues

${ }^{\dagger}$ Corresponding author: C. H. Hagerty; Christina.Hagerty@oregonstate.edu

(c) 2021 The American Phytopathological Society and premature death of tillers (Moya-Elizondo 2013). FCR can also cause a chocolate-brown discoloration one to three internodes up the stem under the leaf sheaths (Bockus et al. 2010) (Fig. 3) as well as reddish hues on wheat stubble (Figs. 4 and 5). FCR is also associated with, but does not always cause, premature ripening of wheat heads, causing the presence of whiteheads. Whiteheads, which are typically filled with shriveled grain, are more likely to occur on plants that were under water stress during anthesis and grain-filling (Alahmad et al. 2018) (Fig. 6).

\section{Host Range}

Along with cereal crops, F. culmorum and F. pseudograminearum can infect other grasses and grassy weeds, such as downy brome and wheat grass and, to a lesser extent, grass genera such as Phalaris and Agropyron (Kazan and Gardiner 2018; Kirby et al. 2017).

\section{Transmission}

FCR is transmitted to plants by inoculum present in the soil or infected stubble (Kirby et al. 2017). Typically, FCR caused by $F$. pseudograminearum and $F$. culmorum has been found to co-occur in crown rot infections (Yin et al. 2020). F. culmorum can be favored over $F$. pseudograminearum in drier soils (Poole et al. 2013). F. culmorum overwinters as chlamydospores, whereas $F$. pseudograminearum overwinters as perithecia on host debris. In low-humidity conditions, the FCR disease cycle is driven primarily by soilborne inoculum residing in the mulch layer of the soil (Bockus et al. 2010). F. culmorum infects wheat seedling roots and stem bases, whereas $F$. pseudograminearum infects wheat seedling stems and tiller bases. If rapid fungal colonization occurs at the seedling stage, damping-off and seedling mortality can occur. A secondary cycle of splash-dispersed conidia can lead to subsequent infection (Bockus et al. 2010).

\section{Geographic Distribution}

FCR is present in all of the cereal-producing parts of the word (Alahmad et al. 2018). FCR is present in approximately $95 \%$ of fields in the Pacific Northwest (Kirby et al. 2017).

\section{Management}

Measures that can be taken to manage FCR infections include planting treated seed, less susceptible cultivars, or cultivars that are less susceptible to water stress. Complete genetic resistance to FCR is not currently available in domesticated germplasm. As 
such, breeding for genetic resistance remains an important breeding objective. Current genetic resistance is quantitative and is impacted by plant physiology and development, as well as the environment. Strategies that employ cultural management in conjunction with partially tolerant cultivars can be effective to reduce disease development (Kazan and Gardiner 2018). Later seeding date can also be effective in managing FCR, because it reduces the chances of water stress in the plants. Crop rotations can also be effective if nonhost crops, such as broadleaf crops, are planted for two years in a row, because inoculum present in the soil at harvest can survive for up to 2 years without a host. Field burning can destroy the fungus still present in the stubble; however, incomplete burns are less effective (Moya-Elizondo 2013). Limiting nitrogen applications can also help manage FCR, because excess nitrogen can exacerbate drought stress (Kirby et al. 2017).

\section{Pathogen Isolation}

Both Fusarium species are readily recovered from diseased plant material. Multiple Fusarium species can be recovered from infected plants, although not all are pathogenic, which makes precise isolation methods important (Leslie and Summerell 2006). Surface sterilization and selective media can be used to identify $F$. culmorum and F. pseudograminearum. For a plant with suspected crown rot infection, root and stem material is washed of any remaining field soil. Lesions and tissue discoloration are typically found at the base of the stem or into the root system, and cross-sections of tissue are excised from the leading edge of the diseased area (Leslie and Summerell 2006). For nonsporulating tissue, surface sterilization is required to remove nonpathogens from tissue surfaces (Leslie and Summerell 2006). Typically, surface sterilization is conducted in a $10 \%$ commercial bleach solution or $70 \%$ ethanol solution for 30 to $60 \mathrm{~s}$, followed by a sterile water soak for 15 to $60 \mathrm{~s}$, depending on the size of the tissue to be sterilized. Producing samples with a range of time in surface sterilization solution and sterile water soak is recommended to account for unknown levels of tissue surface infestation. Plant material is blotted dry and plated onto general Fusarium recovery media of 1/4 strength potato dextrose agar (PDA), or $1 \%$ water agar (WA), or

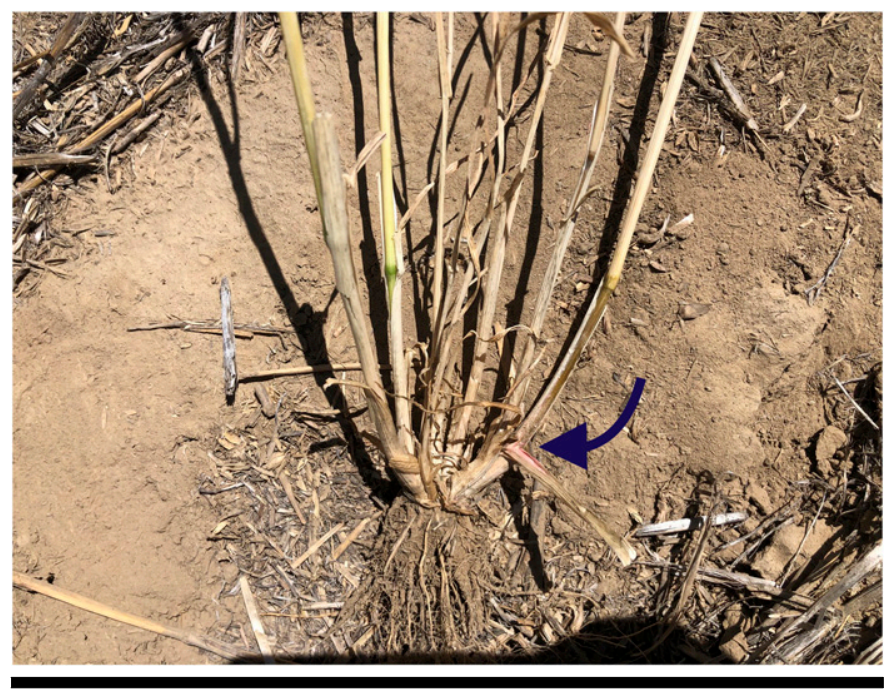

FIGURE 1

Pink mycelium of Fusarium spp. can be visible under leaf sheaths in severe crown rot infection of winter wheat. The arrow on the photo indicates the sign of infection. peptone PCNB agar (PPA), amended with gentamycin antibiotic to inhibit bacterial growth. PPA includes antibiotics and fungicides that inhibit most other fungal and bacterial growth, but it selectively allows for the slow growth of Fusarium spp. (Leslie and Summerell 2006). Additionally, a selective medium has been developed for the recovery of $F$. pseudograminearum. Specific screening medium developed by Summerell and Burgess (1988) allows for distinctive colony formation of $F$. pseudograminearum. If plants have clear sporulation within tissues, surface sterilization may not be attempted in order avoid killing off the pathogen.

\section{Pathogen Identification}

Morphological identification. For morphological identification, further culturing is required. Single-spore isolation is the most accurate way to identify Fusarium isolates, but hyphal-tip extraction is also accepted, especially when colonies lack sporulation (Leslie and Summerell 2006). Following growth on PDA, WA, or PPA, cultures resembling F. culmorum or F. pseudograminearum are transferred via single-spore germination or hyphal-tip extraction to media for sporulation and identification (Leslie and Summerell 2006). Spezieller Nährstoffarmer agar (SNA) and carnation leaf agar have minimal nutrients, which encourages consistent sporulation of Fusarium species for identification (Backhouse et al. 2004; Leslie and Summerell 2006). These media allow for consistent macroconidia, sporodochia, and chlamydospore production.

Both $F$. culmorum and $F$. pseudograminearum lack microconidia (Leslie and Summerell 2006). F. culmorum has short, thick, threeto four-septate macroconidia formed in orange sporodochia, and forms chlamydospores in hyphae and macroconidia (Leslie and Summerell 2006) (Fig. 7). F. pseudograminearum has long, slender, five- to six- (up to 11-) septate macroconidia formed in pale orange sporodochia, and forms chlamydospores less consistently than F. culmorum (Leslie and Summerell 2006).

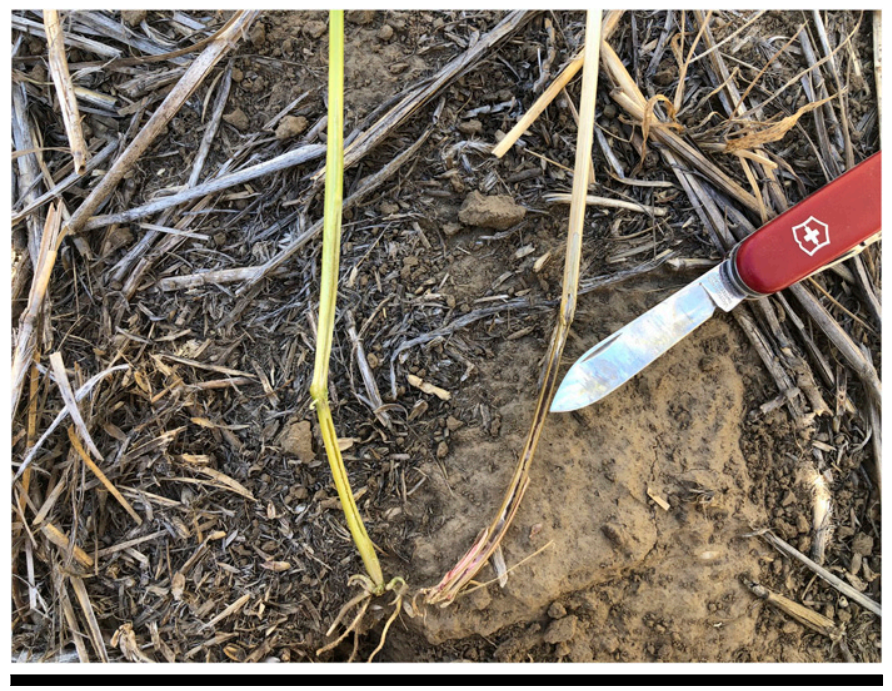

FIGURE 2

Healthy bisected winter wheat tiller (left) compared with Fusarium crown rotinfected tiller (right). White cottony and pink mycelium can be visible where Fusarium has colonized the hollow stem up to the first node. Pocket knife is pointing at the severe Fusarium-infected tiller with pink mycelium visible in the crown tissue below the pocket knife blade (right). 
Molecular identification. Both $F$. culmorum and F. pseudograminearum can be detected and quantified through nucleic acid-based assays (polymerase chain reaction [PCR] and quantitative PCR [qPCR]). PCR primers have been designed to specifically amplify the fragments of the translation elongation factor 1- $\alpha$ gene (TEF1$\alpha$ ) from $F$. culmorum and F. pseudograminearum (Table 1). Primers have been optimized for soil samples surrounding winter wheat roots or infected winter wheat. Total DNA is extracted from soil samples using a commercially available soil DNA extraction kit (e.g., DNeasy PowerSoil Kit, Qiagen, Hilden, Germany) or from infected wheat plants using cetyltrimethyl ammonium bromide (CTAB)-based methods (Brandfass and Karlovsky 2008; Murray and Thompson 1980) or any commercially available plant DNA extraction kit (e.g., DNeasy Plant Mini Kit, Qiagen).

For detection, the fragments of TEF1- $\alpha$ of Fusarium spp. can be amplified from the extracted DNA of tested samples by PCR (Yin et al. 2020). The expected sizes of the production of PCR amplicons (Table 1) can be visualized using agarose gel electrophoresis. PCR amplicons can also be sequenced to provide additional evidence for the presence of Fusarium spp. For quantification, qPCR can be performed using these same species-specific primers (Table 1), and the mass or abundance of Fusarium spp. can be calculated as pathogen DNA/total sample DNA (Yin et al. 2020).

PCR and qPCR protocols. PCR can be performed in a total volume of $25 \mu \mathrm{l}$ using GoTaq DNA Polymerase (Promega, Madison, WI) on any standard laboratory thermocycler. Each $25-\mu \mathrm{l}$ PCR reaction should consist of $5 \mu \mathrm{l}$ of $5 \times$ green GoTaq reaction buffer, $0.5 \mu \mathrm{l}$ of $10 \mathrm{mM}$ dNTPs, $2 \mu \mathrm{l}$ of $25 \mathrm{mM} \mathrm{MgCl}_{2}, 1.25 \mu \mathrm{l}$ of each primer, $2 \mu \mathrm{l}$ of soil DNA (dilute DNA concentration to $2 \mathrm{ng} / \mu \mathrm{l}$ ), $0.125 \mu \mathrm{l}$ of $5 \mu \mathrm{g}$ / $\mu \mathrm{l}$ GoTaq DNA polymerase, and $\mathrm{ddH}_{2} \mathrm{O}$ to a final volume of $25 \mu \mathrm{l}$. The PCR program is as follows: initial denaturing at $95^{\circ} \mathrm{C}$ for 5 min; followed by 30 cycles of $95^{\circ} \mathrm{C}$ for $30 \mathrm{~s}, 60^{\circ} \mathrm{C}$ for $30 \mathrm{~s}$, and $72^{\circ} \mathrm{C}$ for $30 \mathrm{~s}$; with a final extension step at $72^{\circ} \mathrm{C}$ for $5 \mathrm{~min}$.

qPCR can be performed in a total volume of $10 \mu \mathrm{l}$ using KAPA SYBR FAST qPCR Master Mix Kit I (Roche Applied Science, Indianapolis, IN) on any standard laboratory real-time PCR unit.
Each 10- $\mu$ l PCR reaction consists of $5 \mu \mathrm{l}$ of KAPA SYBR FAST qPCR Master Mix, 2 pmol of each primer, $4.6 \mu \mathrm{l}$ of fungal DNA or $2 \mu \mathrm{l}$ of soil DNA (dilute DNA concentration to $2 \mathrm{ng} / \mu \mathrm{l}$ ), and $\mathrm{ddH}_{2} \mathrm{O}$ added to a final volume of $10 \mu \mathrm{l}$.

To generate a standard curve for qPCR, both $F$. culmorum and $F$. pseudograminearum DNAs can be extracted from fungal standards grown in 1/4-strength PDA at room temperature. Mycelial mats should be washed into centrifuge tubes with sterile $\mathrm{ddH}_{2} \mathrm{O}$ and centrifuged at maximum speed. Extract fungal DNAs from the mycelial pellets using the FastDNA Kit (Qbiogene, Carlsbad, CA) according to the manufacturer's instructions and a FastPrep bead beater (MP Biomedical, Santa Ana, CA) using the fungal program.

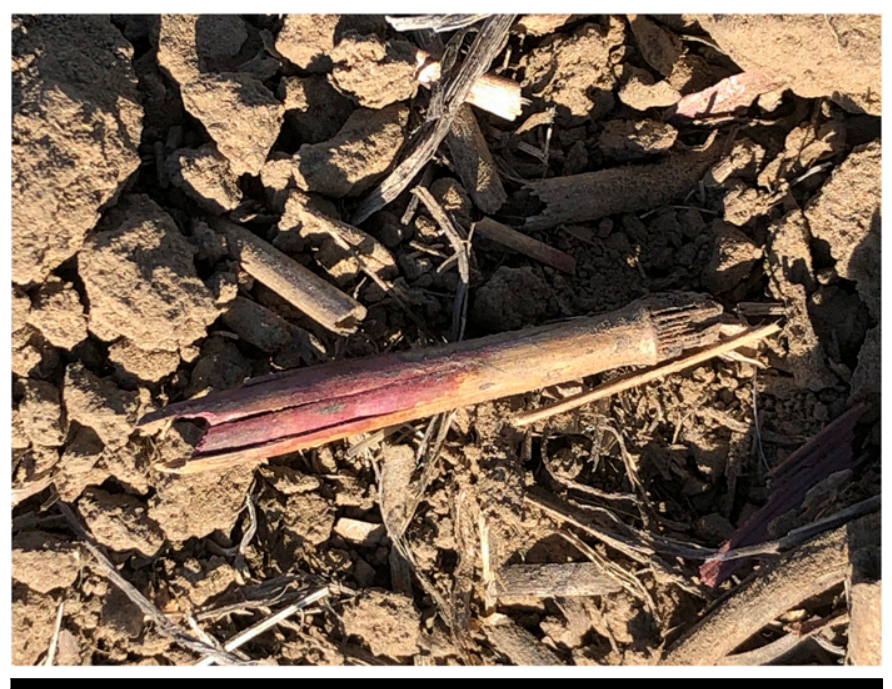

FIGURE 4

Pink colonized winter wheat stubble residue on the soil surface can serve as Fusarium crown rot inoculum source for the subsequent crop.
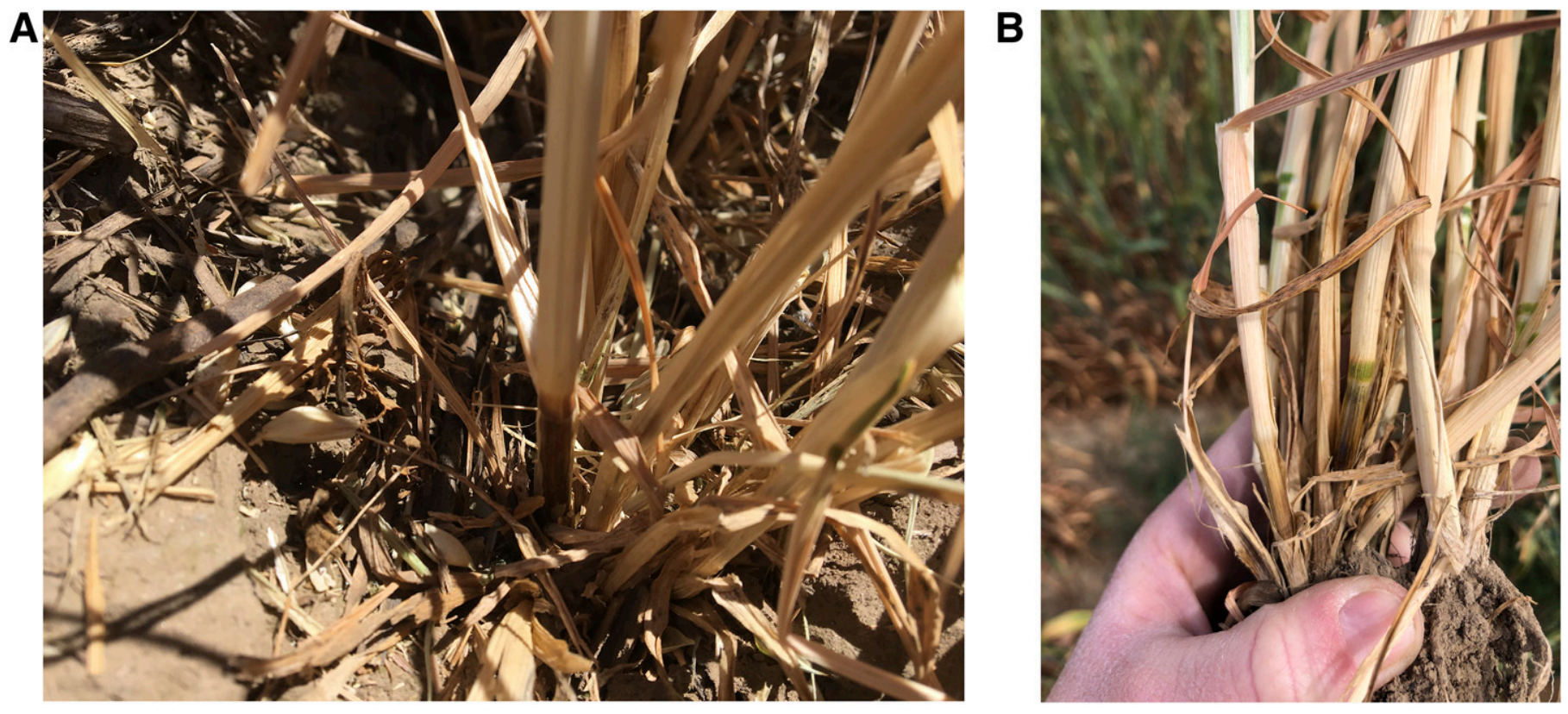

FIGURE 3

A and B, Chocolate browning of lower stem and crown tissue is indicative of Fusarium crown rot infection of winter wheat. 
Standard curves for both $F$. culmorum and $F$. pseudograminearum can be generated using standard DNAs as a template. The DNA concentrations for each fungal pathogen can be series diluted with 10-fold reductions (DNA concentrations from 8 to $0.8 \mathrm{ng} / \mu \mathrm{l}$ ). The PCR program is as follows: an initial denaturation step at $95^{\circ} \mathrm{C}$ for $3 \mathrm{~min}$, followed by 45 cycles of $95^{\circ} \mathrm{C}$ for $10 \mathrm{~s}, 60^{\circ} \mathrm{C}$ for $20 \mathrm{~s}$, and $72^{\circ} \mathrm{C}$ for $1 \mathrm{~s}$. To evaluate amplification specificity, melt curve analysis was generated after each PCR run. A melt curve profile was obtained by heating the mixture to $95^{\circ} \mathrm{C}$ for $5 \mathrm{~s}$, cooling to $65^{\circ} \mathrm{C}$ for $1 \mathrm{~min}$, and then incremental increases of 5 to $10^{\circ} \mathrm{C}$ up to $97^{\circ} \mathrm{C}$ with continuous measurement of fluorescence. We suggest that all samples be amplified in triplicate.

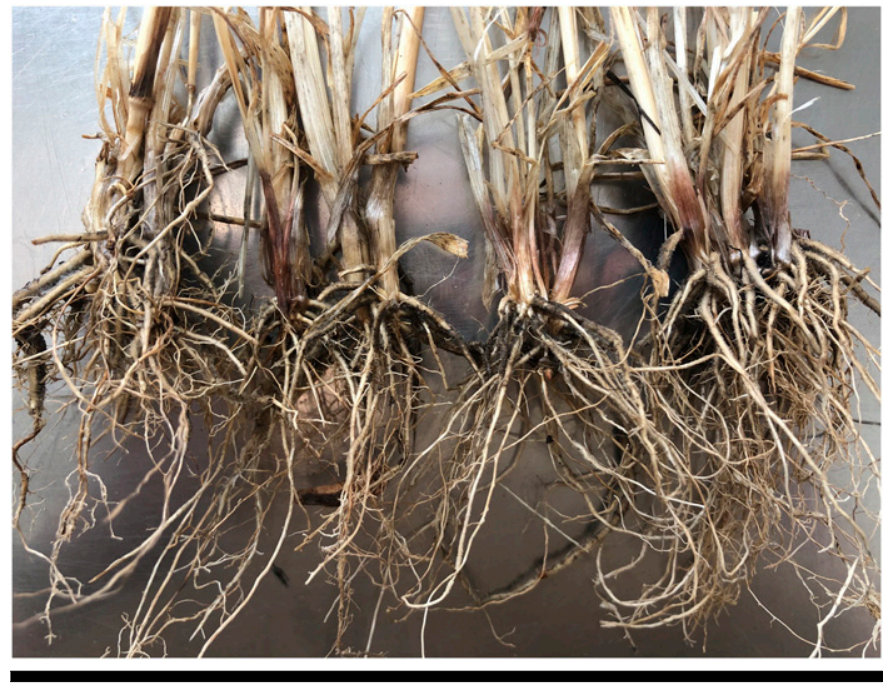

FIGURE 5

Postharvest stubble samples reveal root and crown tissue injury due to Fusarium crown rot.

\section{Pathogen Storage}

Isolates of identified $F$. culmorum and $F$. pseudograminearum can be maintained on SNA because the low level of sugars does not lead to character degradation of colonies (Leslie and Summerell 2006). The authors' preferred method of storage is through freezing at $-70^{\circ} \mathrm{C}$ or colder in glycerol as described by Leslie and Summerell (2006). First, agar slants of SNA are prepared by pouring 1 to $1.25 \mathrm{ml}$ of dissolved, autoclaved medium into $10 \times 75-\mathrm{mm}$ test tubes with cotton and metal or plastic tops for autoclaving. Slants are autoclaved with slow exhaust to prevent lids from falling off the tubes. A small block of a culture for storage is transferred to the cooled slant for 7 to 14 days of growth. A large amount of

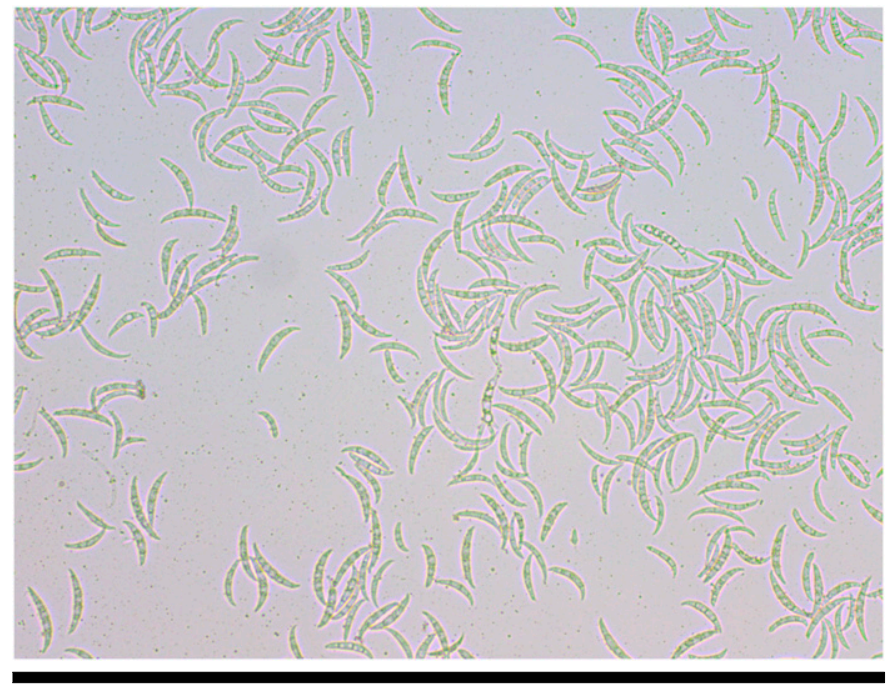

FIGURE 7

Canoe-shaped septate conidia of Fusarium culmorum. Septa constricting swollen cells (center frame) is likely formation of chlamydospores.
A

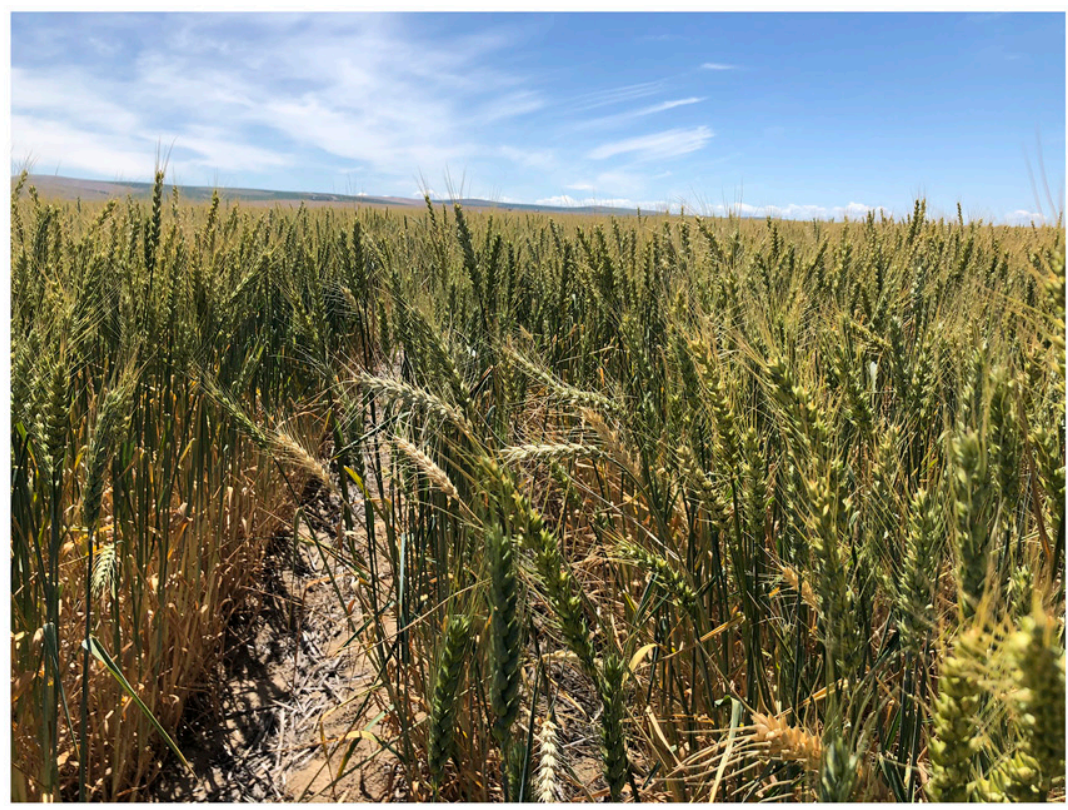

B

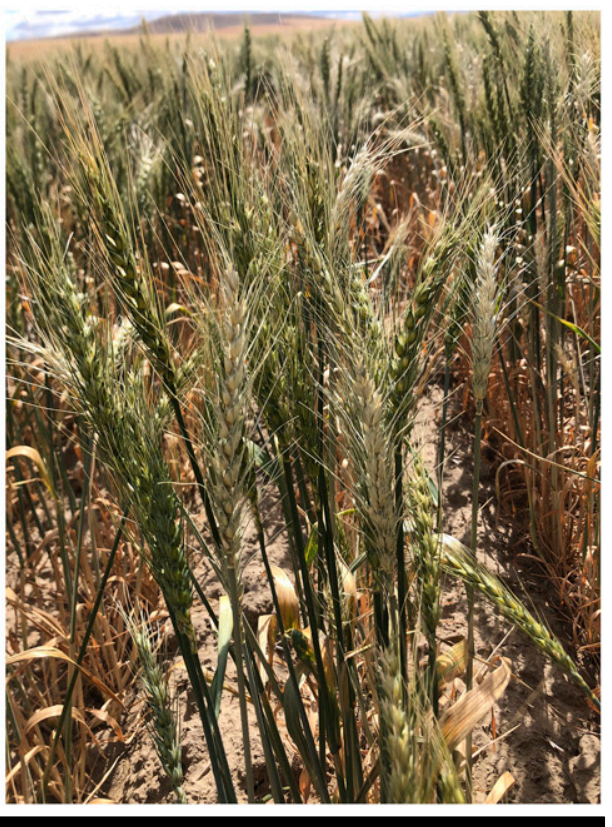

FIGURE 6

A and $\mathbf{B}$, Whiteheads caused by premature senescence with crown rot infection can be visible during grain fill of winter wheat. 
sporulation is desired. When cultures have sporulated adequately, $2 \mathrm{ml}$ of $15 \%$ glycerol solution is added on top of the slants with a Pasteur pipette or other pipette, and the tip is used to agitate the surface of the culture in order to create a spore and hyphal suspension in the glycerol solution. The spore solution is then transferred to a $2 \mathrm{ml}$, or similar, cryovial and placed in a $-70^{\circ} \mathrm{C}$ freezer. When a new culture is needed, one can scrape off some of the ice from the top of the tube and plate it to new SNA medium to start new live cultures. These stored vials are viable for at least 2 years, with some researchers having success with single stored cultures up to 10 years.

Other methods, such as lyophilization, silica gel storage, and soil preservation can be done, but they require specialized equipment (freeze dryer/lyophilizer and silica gel) or have a higher chance of degradation and contamination (soil growth) (Leslie and Summerell 2006).

\section{Pathogenicity Tests}

Several different methods exist to produce FCR inoculum. Isolates of the pathogens can be grown aseptically on sterilized grains, such as wheat, oats, or millet (Smiley 2019). This method is particularly useful for a field trial, because the inoculum can be placed directly with the seed through the planter at the time of planting. Spore suspensions can also be made as a source of inoculum. This can be done by growing isolates on reduced-strength (1/4 or 1/2) PDA for several days, harvesting the spores, and adjusting them to a final concentration of $10^{6}$ spores $/ \mathrm{ml}$. Plants can then be soaked in the spore suspension or the spore suspension can be soaked into the growing medium of the plant (Li et al. 2008).

Pathogenicity testing can be conducted in either greenhouse, growth chamber, or field conditions. For greenhouse and growth chamber tests, typical environmental conditions are a 12-h photoperiod with $25 / 15^{\circ} \mathrm{C}$ day/night temperatures (Mitter et al. 2006).

A number of different rating systems have been published to assess disease severity of crown rot (Ozdemir et al. 2020). These systems include the "leaf sheath sum" system that rates the first three leaf sheaths on a scale from 0 to $4(4=$ dead $)$ and summing those scores. (Wildermuth and McNamara 1994). Another rating system is the crown rot severity index. This index is calculated by dividing the length of stem discoloration by the height of the seedling and then multiplying by the number of necrotic leaf sheath layers (Mitter et al. 2006). A third rating system is the crown rot score system. This system is based on rating the crown tissue discoloration on a 0 to 10 scale $(10=$ dead $)($ Nicol et al. 2001).

In addition to rating severity of crown rot infections, it is also common in the literature to see reports of whitehead counts, indicative of FCR, as a proxy for disease severity (Graebner and Mundt 2019; Smiley et al. 2005). The abundance of rating systems in the literature can be considered, and the appropriate rating system can be selected to best suit the parameters of the experiment. Potential parameters of the experiment could include desired data format, labor available, location of experiment, and so on. It may also be possible to combine and/or execute multiple rating strategies.

\section{Literature Cited}

Alahmad, S., Simpfendorfer, S., Bentley, A. R., and Hickey, L. T. 2018. Crown rot of wheat in Australia: Fusarium pseudograminearum taxonomy, population biology and disease management. Australas. Plant Pathol. 47: 285-299.

Backhouse, D., Abubakar, A. A., Burgess, L. W., Dennis, J. I., Hollaway, G. J., Wildermuth, G. B., Wallwork, H., and Henry, F. J. 2004. Survey of Fusarium species associated with crown rot of wheat and barley in eastern Australia. Australas. Plant Pathol. 33:255-261.

Bockus, W. W., Bowden, R. L., Hunger, R. M., Morrill, W. L., Murray, T. D., and Smiley, R. W., eds. 2010. Fusarium root, crown, and foot rots and other associated seedling diseases. Pages 37-39 in: Compendium of Wheat Diseases and Pests, 3rd Ed. APS Press, St. Paul, MN.

Brandfass, C., and Karlovsky, P. 2008. Upscaled CTAB-based DNA extraction and real-time PCR assays for Fusarium culmorum and F. graminearum DNA in plant material with reduced sampling error. Int. J. Mol. Sci. 9: 2306-2321.

Graebner, R. C., and Mundt, C. C. 2019. 2019 Oregon soft winter elite yield trials - Disease notes. https://agsci.oregonstate.edu/sites/agscid7/files/cropsoil/2019 disease summary_oweyt.pdf (Accessed January 6, 2020).

Kazan, K., and Gardiner, D. M. 2018. Fusarium crown rot caused by Fusarium pseudograminearum in cereal crops: Recent progress and future prospects. Mol. Plant Pathol. 19:1547-1562.

Kirby, E., Paulitz, T., Murray, T., Schroeder, K., and Chen, X. 2017. Disease management for wheat and barley. Pages 399-467 in: Advances in Dryland Farming in the Inland Pacific Northwest. G. Yorgey and C. E. Kruger, eds. Washington State University Extension, Pullman, WA.

Leslie, J. F., and Summerell, B. A. 2006. The Fusarium Laboratory Manual. Blackwell Publishing, Ames, IA. doi.org/10.1002/9780470278376

Li, X., Liu, C., Chakraborty, S., Manners, J. M., and Kazan, K. 2008. A simple method for the assessment of crown rot disease severity in wheat seedlings inoculated with Fusarium pseudograminearum. J. Phytopathol. 156:751754

Mitter, V., Zhang, M. C., Liu, C. J., Ghosh, M., and Chakraborty, S. 2006. A high-throughput glasshouse bioassay to detect crown rot resistance in wheat germplasm. Plant Pathol. 55:433-441.

Moya-Elizondo, E. A. 2013. Fusarium crown rot disease: Biology, interactions, management and function as a possible sensor of global climate change. Cienc. Investig. Agrar. 40:235-252.

Murray, M. G., and Thompson, W. F. 1980. Rapid isolation of high molecular weight plant DNA. Nucleic Acids Res. 8:4321-4326.

Nicol, J. M., Rivoal, R., Trethowan, R. M., Van Ginkel, M., Meroum, M., and Singh, R. P. 2001. CIMMYT's approach to identify and use resistance to nematodes and soil-borne fungi in developing superior wheat germplasm. In: Proceedings of the 6th International Wheat Conference, 5-9 June 2000, Budapest, Hungary. Z. Bedo and L. Lang, eds. Kluwer Academic Publishers, The Netherlands. doi.org/10.1007/978-94-017-3674-9_49

Ozdemir, F., Kemal Koc, N., Paulitz, T., Nicol, L. M., Schroeder, K. L., and Poole, G. 2020. Determination of Fusarium crown rot resistance in wheat to Fusarium culmorum and Fusarium pseudograminearum using real time PCR. Crop Prot. 135:105204.

Poole, G. J., Smiley, R. W., Walker, C., Huggins, D., Rupp, R., Abatzoglou, J., Garland-Campbell, K., and Paulitz, T. C. 2013. Effect of climate on the distribution of Fusarium spp. causing crown rot of wheat in the Pacific Northwest of the United States. Phytopathology 103:1130-1140.

Smiley, R. W. 2019. Mechanized method to inoculate field soil to evaluate Fusarium crown rot of wheat. Plant Dis. 103:2857-2864. 
Smiley, R. W., Gourlie, J. A., Easley, S. A., Patterson, L., and Whittaker, R. G. 2005. Crop damage estimates for crown rot of wheat and barley in the Pacific Northwest. Plant Dis. 89:595-604.

Summerell, B. A., and Burgess, L. W. 1988. Stubble management practices and the survival of Fusarium graminearum group 1 in wheat stubble residues. Australas. Plant Pathol. 17:88-93.
Wildermuth, G. B., and McNamara, R. B. 1994. Testing wheat seedlings for resistance to crown rot caused by Fusarium graminearum group 1. Plant Dis. 78:949-953.

Yin, C., McLaughlin, K., Paulitz, T. C., Kroese, D. R., and Hagerty, C. H. 2020. Population dynamics of wheat root pathogens under different tillage systems in Northeast Oregon. Plant Dis. 104:2649-2657. 